\title{
Device Assembly Facility (DAF) Glovebox Radioactive Waste Characterization
}

\author{
J. L. Dominick
}

$12 / 18 / 01$

U.S. Department of Energy

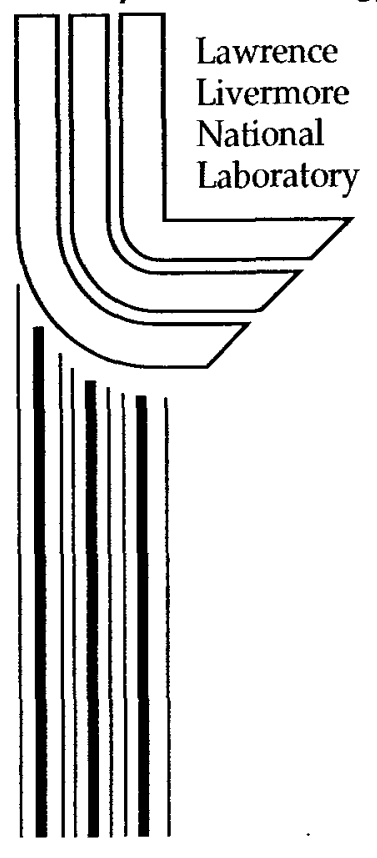




\section{DISCLAIMER}

This document was prepared as an account of work sponsored by an agency of the United States Government. Neither the United States Government nor the University of California nor any of their employees, makes any warranty, express or implied, or assumes any legal liability or responsibility for the accuracy, completeness, or usefulness of any information, apparatus, product, or process disclosed, or represents that its use would not infringe privately owned rights. Reference herein to any specific commercial product, process, or service by trade name, trademark, manufacturer, or otherwise, does not necessarily constitute or imply its endorsement, recommendation, or favoring by the United States Government or the University of California. The views and opinions of authors expressed herein do not necessarily state or reflect those of the United States Government or the University of California, and shall not be used for advertising or product endorsement purposes.

This work was performed under the auspices of the U. S. Department of Energy by the University of California, Lawrence Livermore National Laboratory under Contract No. W-7405-Eng-48.

This report has been reproduced

directly from the best available copy.

Available to DOE and DOE contractors from the

Office of Scientific and Technical Information

P.O. Box 62, Oak Ridge, TN 37831

Prices available from (423) 576-8401

http://apollo.osti.gov/bridge/

Available to the public from the

National Technical Information Service

U.S. Department of Commerce 5285 Port Royal Rd., Springfield, VA 22161

http://www.ntis.gov/

OR

Lawrence Livermore National Laboratory

Technical Information Department's Digital Library

http://www.llnl.gov/tid/Library.html 


\section{Introduction}

The Device Assembly Facility (DAF) at the Nevada Test Site (NTS) provides programmatic support to the Joint Actinide Shock Physics Experimental Research (JASPER) Facility in the form of target assembly. The target assembly activities are performed in a glovebox at DAF and include Special Nuclear Material (SNM). Currently, only activities with transuranic SNM are anticipated. Preliminary discussions with facility personnel indicate that primarily two distributions of SNM will be used: Weapons Grade Plutonium (WG-Pu), and Pu-238 enhanced WG-Pu. Nominal radionuclide distributions for the two material types are included in attachment 1. Wastes generated inside glove boxes is expected to be Transuranic (TRU) Waste which will eventually be disposed of at the Waste Isolation Pilot Plant (WIPP). Wastes generated in the Radioactive Material Area (RMA), outside of the glove box is presumed to be low level waste (LLW) which is destined for disposal at the NTS. The process knowledge quantification methods identified herein may be applied to waste generated anywhere within or around the DAF and possibly JASPER as long as the fundamental waste stream boundaries are adhered to as outlined below. The method is suitable for quantification of waste which can be directly surveyed with the Blue Alpha meter or swiped. An additional quantification methodology which requires the use of a high resolution gamma spectroscopy unit is also included and relies on the predetermined radionuclide distribution and utilizes scaling to measured nuclides for quantification.

\section{Operations overview}

The portion of the facility where the radioactive material is handled in the glove box is maintained as a clean work environment, i.e. no loose contamination in areas outside of the glovebox or in the occupied areas. Several routine procedures are performed to ensure that the facility is maintained as a clean work area. Routine swipes are presently taken both monthly and quarterly throughout the RMA. Hands and shoes are monitored for contamination each time a person exits the RMA. When contamination is found by any of these methods, the source of the contamination is located and decontaminated or encapsulated. Hallways within the RMA are maintained as swipe free. Some potential sources for contamination in the RMA include breaches in glove boxes or other containers, HEPA changes, bag-in / bag-out operations, and glove changes.

The alpha survey instrument used in the DAF is a LLNL designed and manufactured instrument with an air proportional probe (Blue Alpha: LE751854). The minimum detectable activity (MDA) for this instrument under ideal conditions is approximately $50 \mathrm{cpm}$ with $50 \%$ efficiency $=\sim 100 \mathrm{dpm}$. This portable instrument has a $100 \mathrm{~cm}^{2}$ probe. 

Use of administrative controls will be employed to segregate waste and conduct preliminary waste categorization. Waste generated within the glovebox and bagged out will be handled and packaged as TRU waste. Waste generated in the RMA outside of the glovebox will be packaged and handled as LLW. Waste generated outside of the glovebox is assumed to be non-contaminated. In the event of a spill or release, waste associated with the cleanup and any waste generated outside of the glovebox with measurable contamination on the blue alpha meter will be handled as TRU waste.

LLW activity will be quantified using the mass of the waste in the entire drum as if it all was contaminated at the MDA of the blue alpha.

TRU waste activity will be conservatively estimated using the mass of waste in each parcel and the highest contamination level measured on any surface in the parcel. The measurement of the high activity can be from direct survey or from a swipe survey with appropriate correction factors applied as outlined below.

\section{Waste Characterization}

\section{Distribution development}

When characterizing radioactive waste, knowledge of the radioactive isotopes contaminating the waste is required. Radioactive material and contamination is often a mixture of individual radioactive isotopes. The relative abundance of individual radioactive isotopes to the total activity or mass of the material or contamination is defined as the distribution. Input data for distribution development is often in the form of mass fractions however this must be converted to activity fractions for waste characterization. Distribution activity fractions are fractions of the total activity of the distribution regardless of decay mode. See attachment 1 for some nominal radionuclide distributions. These generic radionuclide distributions are used across LLNL Hazardous Waste Management (HWM) where applicable to characterize waste for disposal at the NTS and for WIPP. Additional project specific isotopic distributions may be developed using inventory controls, process knowledge, and historical analytical data if needed. As additional distributions are developed they will be documented on a case-by-case basis in later revisions of this document or project specific documentation such as Process Knowledge Evaluations (PKEs).

Radiological Characterization for transuranic nuclide contaminated waste coming from the DAF requires both an isotopic breakdown (distribution) and documented methods for quantification of the radionuclides in the waste. 
Isotopic quantification will be done using information from the radiological control program in the facility. Specifically documented direct survey results with the blue alpha (gross radiation measurement), and/or documented swipe survey results (swipe to curie). Other methods may be employed as needed such as, gamma spectroscopy, laboratory analytical, or radionuclide scaling. Specific approaches to radiological identification and/or quantification other than methods documented here shall be documented and approved as they are developed and put into use. It should be noted that these quantification methods providing bounding radionuclide activities which the waste should not reasonably be expected to exceed. These bounding activities should be used for preliminary waste categorization, waste handling, and waste acceptance purposes. These methods are adequate to characterize LLW for disposal. However, TRU waste will require a WIPP certified analysis prior to disposal at WIPP. TRU waste should be packaged with consideration given to LLW certification requirements as some of this waste will undoubtedly be reclassified as LLW as a result of WIPP assay. Swipe and survey quantification techniques are only applicable to surface contaminated waste with measurable surfaces. Volumetrically contaminated waste should not be characterized using swipe and survey techniques.

\section{Quantification}

Four quantification methodologies for use at the DAF are described in detail below:

\section{A. Gross radiation measurement using the blue alpha:}

The following general equations demonstrate how TRU waste and LLW contaminated with alpha emitting radionuclides in a known distribution can be quantified using the blue alpha meter.

Meter efficiency correction is conducted as follows:

$$
G A_{x}=\frac{G C_{x}}{E f f_{x}} \quad \text { EqA1. }
$$

Where: $\mathrm{GA}_{\mathrm{x}}=$ Gross activity as measured with instrument $\mathrm{x}(\mathrm{dpm})$.

$\mathrm{GC}_{\mathrm{x}}=$ Gross count rate as measured with instrument $x(\mathrm{cpm})$.

Eff $_{x}=$ Efficiency of instrument $x$ ( 0.5 for the blue alpha).

Gross activity measured to waste activity material concentration calculations are conducted using the following algorithm: 


$$
G C_{y}=\frac{\left(G A_{x}\right)\left(K_{a c t}\right)\left(S_{y}\right)}{\left(A D_{y}\right)\left(S A_{x}\right)} \quad \text { EqA2. }
$$

Where: $\mathrm{GC}_{\mathrm{y}}=$ Gross activity concentration of waste material y $(\mathrm{nCi} / \mathrm{g})$.

$\mathrm{GA}_{\mathrm{x}}=$ Gross activity as measured with instrument $\times(\mathrm{dpm})$.

$\mathrm{K}_{\mathrm{act}}=$ Activity conversion factor $(4.5 \mathrm{E}-04 \mathrm{nCi} / \mathrm{dpm})$.

$\mathrm{S}_{\mathrm{y}}=$ Number of sides of item $\mathrm{y}$ which are contaminated (i.e. 1 or 2)

$\mathrm{AD}_{\mathrm{y}}=$ Areal Density of waste material y $\left(\mathrm{g} / \mathrm{cm}^{2}\right)$.

$\mathrm{SA}_{\mathrm{x}}=$ Surface area of probe on instrument $x\left(\mathrm{~cm}^{2}\right)$.

Gross activity concentration to total parcel gross activity conversions are conducted using the weight of the parcel as outlined below:

$$
T G A_{z}=\left(G C_{y}\right)\left(M_{z}\right)
$$

Where: $\mathrm{TGA}_{z}=$ Total gross activity of parcel $z(\mathrm{nCi})$.

$\mathrm{GC}_{\mathrm{y}}=$ Gross activity concentration of waste material y $(\mathrm{nCi} / \mathrm{g})$. $\mathrm{M}_{\mathrm{z}}=$ Mass of parcel $\mathrm{z}(\mathrm{g})$.

Conversion of total measured gross activity to total radioactivity and isotopic activity in the parcel requires knowledge of the isotopic composition (distribution) of the material being surveyed and the decay mode and probability of decay through the measured decay mode of each isotope. Suffice it to say that for known distributions of material, activity per decay mode can be calculated. A ratio of the decay mode specific activity and the total activity (regardless of decay mode) can be used to calculate total activity from measurements of a single type of radiation resulting from a single decay mode such as alpha decay. The ratio is calculated as follows:

$$
K_{d e c}=\frac{\left(S p A_{d m}\right)}{\left(S p A_{t o t}\right)}
$$

Where: $\mathrm{K}_{\mathrm{dec}}=$ Correction factor, gross measured activity to total activity. 
$\mathrm{SpA}_{\mathrm{dm}}=$ Decay mode specific, specific activity for the distribution.

$\mathrm{SpA}_{\mathrm{tot}}=$ Total Specific activity for the distribution.

Conversion of gross total parcel activity to total parcel activity is conducted as follows:

$$
T A=\frac{\left(T G A_{z}\right)}{\left(K_{d e c}\right)} \quad \text { EqA5. }
$$

Where: $\mathrm{TA}=$ Total Activity of parcel $\mathrm{z}(\mathrm{nCi})$.

$\mathrm{TGA}_{\mathrm{z}}=$ Total gross activity of parcel $\mathrm{z}(\mathrm{nCi})$.

$\mathrm{K}_{\mathrm{dec}}=$ Correction factor, gross measured activity to total activity.

Using the appropriate fractional abundance, the specific isotope activities can be calculated using the following algorithm:

$$
A_{i}=(T A)\left(A_{\text {frac }}\right) \quad \text { EqA6. }
$$

Where: $A_{i}=$ Activity of radionuclide, $i$, within the parcel.

$\mathrm{TA}=$ Total Activity of parcel $\mathrm{z}$ (nCi).

$A_{\text {frac }}=$ Fractional abundance of radionuclide, $i$, within the distribution.

\section{B. Gross radiation measurement using a Swipe}

This technique is really a hybrid cross between smear to curie and gross radiation measurement using the blue alpha. For the DAF it is anticipated that the swipe will be used in place of the blue alpha meter. The swipe would then be counted on a gas flow proportional counter and only the gross alpha activity entered into the spreadsheet. The gas flow proportional counter results should already be corrected for efficiency of the counter giving results of gross alpha with units of dpm/swipe. Modification of Equation A2 allows us to use swipe data in place of direct survey data. Term $\mathrm{GA}_{\mathrm{x}}$ is replaced by term $\mathrm{GA}_{\mathrm{sw}}$, term $\mathrm{SA}_{\mathrm{x}}$ is replaced by term $\mathrm{SA}_{\mathrm{sw}}$ and a new term, $\mathrm{E}_{\mathrm{sw}}$, is added to allow correction for swipe efficiency. When using the swipe to assess gross contamination on waste, a conservative swipe efficiency must be included in the calculation. Gross activity 
measured on the swipe to waste material activity concentration calculations are conducted using the following algorithm:

$$
G C_{y}=\frac{\left(G A_{s w}\right)\left(K_{a c t}\right)\left(S_{y}\right)}{\left(A D_{y}\right)\left(S A_{s w}\right)\left(E_{s w}\right)} \quad \text { EqB1. }
$$

Where: $\mathrm{GC}_{\mathrm{y}}=$ Gross activity concentration of waste material y $(\mathrm{nCi} / \mathrm{g})$.

$\mathrm{GA}_{\mathrm{sw}}=$ Gross activity on the swipe (dpm).

$\mathrm{K}_{\mathrm{ac}}=$ Activity conversion factor $(4.5 \mathrm{E}-04 \mathrm{nCi} / \mathrm{dpm})$.

$\mathrm{S}_{\mathrm{y}}=$ Number of sides of item y which are contaminated (i.e. 1 or 2 )

$\mathrm{AD}_{\mathrm{y}}=$ Areal Density of waste material y $\left(\mathrm{g} / \mathrm{cm}^{2}\right)$.

$\mathrm{SA}_{\mathrm{sw}}=$ Surface area swiped $\left(\mathrm{cm}^{2}\right)$.

$\mathrm{E}_{\mathrm{sw}}=$ Swipe efficiency.

Parcel quantification is completed by application of equations A3 through A6 using term $\mathrm{GC}_{\mathrm{y}}$ from $\mathrm{EqB} 1$.

Alternatively the swipe could be counted on a different instrument, such as a gamma spec, or subjected to destructive analytical methods for isotopic results. The method could then be modified to use scaling in conjunction with the isotopic results.

\section{Scaling using gamma spectroscopy.}

Proper application of scaling requires detailed knowledge of the radionuclide distribution. Scaling is the process of quantifying unmeasured radionuclides in a distribution by measurement of a single nuclide and application of scaling factors. Each unmeasured isotope in a distribution has a scaling factor to the single measured isotope. An individual scaling factor is calculated as the ratio of the unmeasured isotope fractional abundance to the measured isotopes fractional abundance. For the DAF it is anticipated that gamma spectroscopy will be conducted on whole parcels of waste. The gamma spec results will be corrected for efficiency, geometry, and matrix effects. The results shall be reported as the total parcel activity for a single isotope (as measured from one peak or several). The single isotope used for Pu mixtures is usually Am-241 or Pu-239 but could be any other easily measurable nuclide in the distribution. The parcels should be small and contain only low $\mathrm{Z}$ material and should be wrapped only in plastic. If the parcel is non-detect the corrected MDA can be used in the formula for the isotopic activity. The following algorithm is used to estimate the activity of each isotope in the parcel: 


$$
A_{i}=\left(A_{s i}\right)\left(S F_{i}\right)
$$

\section{$\mathrm{EqC1}$.}

Where: $A_{i}=$ Total activity of radionuclide, $i$, within the parcel.

$\mathrm{A}_{\mathrm{si}}=$ Total activity of scaled isotope within the parcel.

$\mathrm{SF}_{\mathrm{i}}=$ Scaling factor for radionuclide, $\mathrm{i}$, relative to $\mathrm{si}$

\section{Gross radiation screening (PK Quantification) using the blue alpha MDA.}

This is a modification to the gross radiation measurement technique, A, above. The blue alpha meter is used to screen waste and to quantify waste contaminated at or below the MDA of the blue alpha. Equations A1 through A6 are used with several small modifications. The modifications consist of using conservative assumptions to bound the potential activity in the waste. Some of the assumptions are outlined below:

1. $S_{y}=1$, The waste material is contaminated on one side and the contamination is equally distributed.

2. $\mathrm{SD}_{\mathrm{p}}=$ The waste has the same surface area per weight as 6 mil plastic. 6 mil plastic sheet has a areal density of $1.2 \mathrm{E}-02 \mathrm{~g} / \mathrm{cm}^{2}$.

3. $\quad \mathrm{MDA}_{\mathrm{b}}=$ The alpha meter used to measure the area is $50 \%$ efficient and the minimum detectable activity is $2.5 \mathrm{cpm} / \mathrm{cm}^{2}=\sim 5 \mathrm{dpm} / \mathrm{cm}^{2}$.

4. All waste is contaminated at the MDA.

Assumption 1 is generally true in that only one side of most items will come in contact with the radioactive material.

Assumption 2 provides a method to convert surface area to weight. Six-mil plastic was chosen because it is one of the lighter items disposed of as waste and therefore provides a conservative estimate of the activity in the waste. Low areal density values are conservative because they equate to higher activity per a given weight.

Assumption 3 uses a $\mathrm{MDA}_{\mathrm{b}}$ of $2.5 \mathrm{cpm} / \mathrm{cm}^{2}=\sim 5 \mathrm{dpm} / \mathrm{cm}^{2}$ which is 5 times the actual $\mathrm{MDA}_{\mathrm{b}}$ of $0.5 \mathrm{cpm} / \mathrm{cm}^{2}=\sim 1 \mathrm{dpm} / \mathrm{cm}^{2}$ for the LLNL Blue. Alpha Meter. A $\mathrm{MDA}_{\mathrm{b}}$ of $0.5 \mathrm{cpm} / \mathrm{cm}^{2}=\sim 1 \mathrm{dpm} / \mathrm{cm}^{2}$ is for the ideal flat and smooth surface and the $\mathrm{MDA}_{\mathrm{b}}$ of $2.5 \mathrm{cpm} / \mathrm{cm}^{2}=\sim 5 \mathrm{dpm} / \mathrm{cm}^{2}$ is to provide for surfaces that are not ideal. 
Assumption 4 provides an estimate of the quantity of activity in the waste. By using the MDA for all material this will help ensure that the quantity of alpha emitters in the waste is not under estimated.

By converting surface area contaminated at MDA weight it is determined that the waste will contain approximately $0.20 \mathrm{nCi}$ per gram. Equation A2 is modified to include the assumptions. Term $\mathrm{GA}_{\mathrm{x}}$ is replaced by term $\mathrm{MDA}_{\mathrm{b}}$ which is the MDA of the blue alpha meter. Term $S A_{x}$ is dropped as the MDA is expressed in terms of $\mathrm{dpm} / \mathrm{cm}^{2}$. Term Sy is dropped because we have assumed only one side of the waste is contaminated (really none are). The following calculation demonstrates the quantification:

$$
G C_{y}=\frac{\left(M D A_{b}\right)\left(K_{a c t}\right)}{\left(A D_{y}\right)}=0.19 \approx 0.20 n C i / g
$$

Where: $\mathrm{GC}_{\mathrm{y}}=$ Gross activity concentration of waste material y $(\mathrm{nCi} / \mathrm{g})$. $\mathrm{MDA}_{\mathrm{b}}=$ Conservative MDA for the blue alpha $\left(5 \mathrm{dpm} / \mathrm{cm}^{2}\right)$. $\mathrm{K}_{\text {act }}=$ Activity conversion factor $(4.5 \mathrm{E}-04 \mathrm{nCi} / \mathrm{dpm})$. $\mathrm{AD}_{\mathrm{y}}=$ Areal Density of waste material y $\left(1.2 \mathrm{E}-02 \mathrm{~g} / \mathrm{cm}^{2}\right)$.

Waste quantification can now be completed through application of equations A3 through A6.

\section{Areal Density}

The following table provides a sampling of common waste materials and their respective areal densities:

\begin{tabular}{|c|c|}
\hline Item & Areal Density $\left(\mathrm{g} / \mathrm{cm}^{2}\right)$ \\
\hline Six-mil Plastic Sheet & $1.2 \mathrm{E}-02$ \\
\hline 20\# Copier Paper & $1.0 \mathrm{E}-02$ \\
\hline Powderless Gloves & $2.0 \mathrm{E}-02$ \\
\hline Heavy Rubber Gloves & $4.8 \mathrm{E}-02$ \\
\hline Plastic and Launderable Shoe Covers & $1.2 \mathrm{E}-01$ \\
\hline Coverall Material & $1.9 \mathrm{E}-02-2.8 \mathrm{E}-02$ \\
\hline Twelve-mil Plastic & $2.4 \mathrm{E}-02$ \\
\hline
\end{tabular}


Application of quantification methodologies to DAF waste.

LLW will be quantified using method $\mathrm{D}$ or $\mathrm{C}$ on a case-by-case basis. All waste from within the glovebox and contaminated waste generated outside of the glovebox will be handled as TRU waste. Waste from inside the glovebox is considered guilty by association and waste from outside the glovebox contaminated above MDA of the blue alpha is to be handled as TRU for conservatism.

Waste with measurable activity will be handled and packaged as TRU waste pending WIPP certified analysis. If waste re-classification is necessary it can be conducted after the WIPP certified analysis is conducted. Any WIPP certified analysis will also be adequate to quantify radioactivity for certification as LLW.

TRU waste must always be documented and tracked at the parcel level but LLW may be documented at the drum level when characterized by method $D$.

When quantifying TRU waste the highest gross alpha activity measured on the item must be entered into the quantification spreadsheet to quantify the isotopic activity in each parcel of TRU waste.

Attachments 2 through 5 are samples of the quantification spreadsheets to be used for waste quantification. The spreadsheet to use is dependent on the quantification methodology being employed. The waste stream summary sheets will provide additional guidance on waste handling and packaging.

\section{Justification for using MDA for activity calculations of LLW:}

Waste will undergo direct survey with the blue alpha meter. Waste with measurable contamination will be segregated from waste that is at or below the MDA of the blue alpha meter. Segregation of contaminated waste from $<$ MDA waste will be conducted when waste is being packaged. Waste with measurable contamination will be quantified based upon actual instrument readings, swipe to curie conversions, or other documented methods as appropriate. The MDA characterization method is only for material with no measurable contamination. 


\section{Conclusions:}

By using these radiological quantification methods as described to determine the quantity of alpha emitters in a waste container it can be ensured that waste items contaminated with TRU levels of alpha emitters will not end up in the low level waste stream. Additionally TRU waste can be adequately and conservatively characterized to allow for proper storage pending WIPP certified analysis.

\section{Attachments:}

1. Nominal Pu distributions.

2. DAF blue alpha meter MDA spreadsheet.

3. DAF Total alpha activity to isotopic activity spreadsheet.

4. DAF worksheet for scaling to Pu-239.

5. DAF worksheet for scaling to Am-241.

6. DAF swipe to isotopic activity spreadsheet.

7. DAF blue alpha survey to isotopic activity spreadsheet. 



\begin{tabular}{|c|c|c|c|c|c|c|c|}
\hline Type of $\mathrm{Pu}$ & Isotope & $\begin{array}{c}\text { Weight } \\
(\%)\end{array}$ & $\begin{array}{l}\text { Weight } \\
\text { Fraction }\end{array}$ & $\begin{array}{c}\mathrm{SpA} \\
(\mathrm{Ci} / \mathrm{g})\end{array}$ & $\begin{array}{c}\text { Mixture SpA } \\
\quad(\mathrm{Ci} / \mathrm{g})\end{array}$ & $\begin{array}{l}\text { Activity } \\
\text { Fraction }\end{array}$ & $\begin{array}{c}\text { Activity \% } \\
(\%)\end{array}$ \\
\hline Woapons Grates & 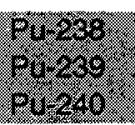 & $\begin{array}{l}1.60 \mathrm{E}-02 \\
9.35 \mathrm{E}+01 \\
8.90 \mathrm{E}+00\end{array}$ & $\begin{array}{l}1.60 \mathrm{E}-04 \\
9.95 \mathrm{E} .02 \\
8.90 \mathrm{C} .02\end{array}$ & $\begin{array}{r}1.78 \mathrm{E}+01 \\
6.30 \mathrm{E}-02 \\
2.30 \mathrm{E}-01\end{array}$ & $\begin{array}{l}2.77 \mathrm{E} .98 \\
5.80 \mathrm{E} 02 \\
1.36 \mathrm{E}-02\end{array}$ & 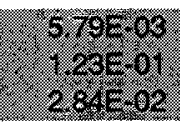 & 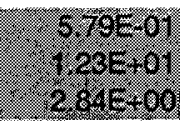 \\
\hline & $\mathrm{Pu}-241$ & $3.81 E-01$ & $3.81 E-03$ & $1.04 E+02$ & $3.96 \mathrm{E}-01$ & $8.28 E-01$ & $8.28 \mathrm{E}+01$ \\
\hline & 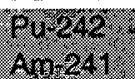 & $\begin{array}{l}400 \mathrm{E}=02 \\
2.01 \mathrm{E}-01\end{array}$ & $\begin{array}{c}4.00 \mathrm{E} 04 \\
2.01 \mathrm{E} .03\end{array}$ & $\begin{array}{l}.0 .0 E-03 \\
3.47 E+00\end{array}$ & $\begin{array}{l}1.60 \mathrm{E}-06 \\
6.97 \mathrm{E} .08\end{array}$ & $\frac{3.64 \mathrm{~F}}{1.66}$ & $\begin{array}{c}3.34 \mathrm{E}=04 \\
1.46 \mathrm{E} .00\end{array}$ \\
\hline & & $1.00 \mathrm{E}+02$ & $1.00 \mathrm{E}+00$ & & $4.78 \mathrm{E}-01$ & $1.00 \mathrm{E}+00$ & $1.00 \mathrm{E}+0$ \\
\hline
\end{tabular}

\begin{tabular}{|c|c|c|c|c|c|c|c|}
\hline Fuel crade & mithe & 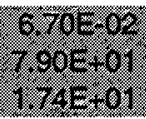 & 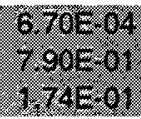 & $\begin{array}{c}178 \mathrm{E}+01 \\
630 \mathrm{E} 02 \\
230 \mathrm{CO}\end{array}$ & $\begin{array}{r}1.6 \mathrm{E}=02 \\
4.97 \mathrm{E} .02 \\
4.01 \mathrm{E}=02\end{array}$ & 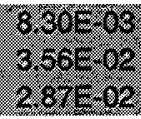 & 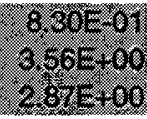 \\
\hline & $\mathrm{Pu}-241$ & $1.18 E+00$ & $1.18 \mathrm{E}-02$ & $1.04 E+02$ & $1.23 E+00$ & $8.79 \mathrm{E}-01$ & $8.79 E+01$ \\
\hline & $\begin{array}{l}\text { P0.242 } \\
\text { Am-24 }\end{array}$ & $\begin{array}{c}4.80 \mathrm{E} .01 \\
194 \mathrm{E}+00\end{array}$ & $\begin{array}{r}4.30 \mathrm{CO} \\
1.94 \mathrm{E} .02\end{array}$ & $\begin{array}{l}4.00 \mathrm{E}-06 \\
3.47 \mathrm{E}+00\end{array}$ & $\begin{array}{l}1.2 \mathrm{E}-65 \\
6.3 \mathrm{E} .02\end{array}$ & $\begin{array}{l}123 E-65 \\
482 E-02\end{array}$ & $\begin{array}{l}1.23 E=0 \\
4.82 E+00\end{array}$ \\
\hline & & $1.00 E+02$ & $1.00 E+00$ & & $1.40 E+00$ & $1.00 E+00$ & $1.00 E+02$ \\
\hline
\end{tabular}

\begin{tabular}{|c|c|c|c|c|c|c|c|}
\hline Peactor Grade & 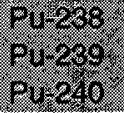 & $\begin{array}{l}1.9 \mathrm{ge}=02 \\
7.37 \mathrm{C}+01 \\
2.49 \mathrm{C}+01\end{array}$ & $\begin{array}{l}1.10 \mathrm{E} 04 \\
7.37 \mathrm{E} 01 \\
2.49 \mathrm{E} .01\end{array}$ & $\begin{array}{l}1.76 \mathrm{E}+04 \\
6.30 \mathrm{E} .02 \\
2.80 \mathrm{E} .01\end{array}$ & $\begin{array}{l}1.90 \mathrm{E}-08 \\
4.64 \mathrm{E}-02 \\
5.79 \mathrm{E}-02\end{array}$ & $\begin{array}{l}8.28 \mathrm{c} 0 \mathrm{c} \\
7.98 \mathrm{C} \\
9.6 \mathrm{C}\end{array}$ & 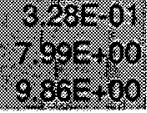 \\
\hline & $\mathrm{Pu}-241$ & $4,24 \mathrm{E}-01$ & $4.24 \mathrm{E}-03$ & $1.04 E+02$ & 4.41E-01 & 7.59E-01 & $7.59 E+01$ \\
\hline & $\begin{array}{l}\text { PQre42 } \\
\text { An-241 }\end{array}$ & $\begin{array}{l}1.60 \mathrm{E}-02 \\
9.94 \mathrm{E} 01\end{array}$ & $\begin{array}{l}1.80 \mathrm{E} 04 \\
9.94 \mathrm{E} 03\end{array}$ & $\begin{array}{l}400 \mathrm{E}-03 \\
3.47 \mathrm{E}+00\end{array}$ & $\begin{array}{l}7.20 \mathrm{E}-07 \\
3.45 \mathrm{E}-02\end{array}$ & $\begin{array}{l}1.24 \mathrm{E}-06 \\
5.94 \mathrm{E}-02\end{array}$ & $\begin{array}{l}1.24 E .04 \\
5.94=100\end{array}$ \\
\hline & & $1.00 \mathrm{E}+02$ & $1.00 E+00$ & & $5.81 \mathrm{E}-01$ & $1.00 E+00$ & $1.00 \mathrm{E}+02$ \\
\hline
\end{tabular}

\begin{tabular}{|c|c|c|c|c|c|c|c|}
\hline Americrum Enriched & 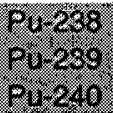 & 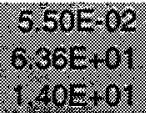 & 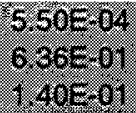 & $\begin{array}{l}1.78 \mathrm{E}+01 \\
6.80 \mathrm{E}-12 \\
2.80 \mathrm{C} 01\end{array}$ & $\begin{array}{c}9.5 \mathrm{E}-03 \\
4.00 \mathrm{E}-02 \\
9.20 \mathrm{E}-02\end{array}$ & $\frac{5,20403}{2,29}$ & 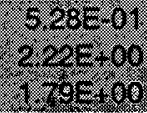 \\
\hline & Pu-241 & 9.50E-01 & $9.50 \mathrm{E}-03$ & $1.04 E+02$ & $9.88 \mathrm{E}-01$ & $5.49 E-01$ & $5.49 E+01$ \\
\hline & $\begin{array}{l}P=242 \\
\text { Am- } 241\end{array}$ & $\begin{array}{l}3.46 E+1 \\
2.1 . E+01\end{array}$ & $\begin{array}{l}3.46=03 \\
2.11=01\end{array}$ & $\begin{array}{c}4.00 \mathrm{E} 03 \\
3.7 \mathrm{E}+00\end{array}$ & $\begin{array}{l}1.38 \mathrm{E} 05 \\
7.31 \mathrm{E}-01\end{array}$ & $\begin{array}{l}7.68 \mathrm{E}-06 \\
4.06 \mathrm{E}-01\end{array}$ & $\begin{array}{c}7.65 \mathrm{E} 04 \\
4.05 \mathrm{E}-1\end{array}$ \\
\hline & & $1.00 E+02$ & $1.00 E+00$ & & $1.80 E+00$ & $1.00 E+00$ & $1.00 E+02$ \\
\hline
\end{tabular}

\begin{tabular}{|c|c|c|c|c|c|c|c|}
\hline Mared Pu. & Plops & 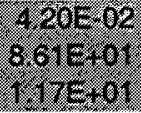 & 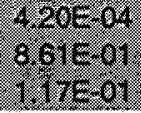 & $\begin{array}{l}1.75 E .01 \\
6.36=02 \\
2.3501\end{array}$ & 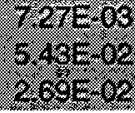 & 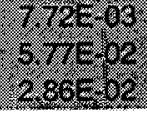 & 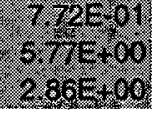 \\
\hline & $\mathrm{Pu}-241$ & $7.84 E-01$ & $7.84 \mathrm{E}-03$ & $1.04 E+02$ & 8.15E-01 & $8.66 \mathrm{E}-01$ & 8.66E+01 \\
\hline & $\begin{array}{l}\text { Pu-242 } \\
\text { An-241 }\end{array}$ & $\begin{array}{l}2.36 E-01 \\
1.08 E+00\end{array}$ & $\begin{array}{l}2.36 \mathrm{E} 08 \\
1.08=02\end{array}$ & $\begin{array}{l}4.00 \mathrm{E}=08 \\
3.47 \mathrm{E}, 00\end{array}$ & $\begin{array}{l}9.44 E=6 \\
3.74 \text { E-62 }\end{array}$ & $\begin{array}{l}1.00 \mathrm{e} 05 \\
3.98 \mathrm{E} 02\end{array}$ & $\begin{array}{l}1.00 \mathrm{E} \\
3.96 \mathrm{E} \\
3.00\end{array}$ \\
\hline & & $1.00 E+02$ & $1.00 E+00$ & & 9.41E-01 & $1.00 E+00$ & $1.00 \mathrm{E}+02$ \\
\hline
\end{tabular}

\begin{tabular}{|c|c|c|c|c|c|c|c|}
\hline Po-238 onhancod & 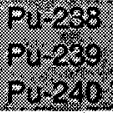 & $\begin{array}{l}8.02 E+10 \\
8.56=01 \\
5.50=-00\end{array}$ & $\begin{array}{l}8.02 \mathrm{e} .02 \\
8.55 \mathrm{c}-1 \\
5.20 \mathrm{E}-12\end{array}$ & $\begin{array}{l}1.78 \mathrm{E}+01 \\
6.30=02 \\
2.0201\end{array}$ & $\begin{array}{l}1.96 \mathrm{E}+00 \\
5.38 \mathrm{E}-02 \\
.66 \mathrm{E} .02\end{array}$ & 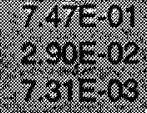 & $\begin{array}{c}7.47 \mathrm{E}+01 \\
2.90 \mathrm{E}+00 \\
7.3 \mathrm{E}=01\end{array}$ \\
\hline & $\mathrm{Pu}-241$ & 3.81E-01 & $3.81 E-03$ & $1.04 \mathrm{E}+02$ & $3.96 \mathrm{E}-01$ & $2461=07$ & 2.13E+01 \\
\hline & $\begin{array}{l}\text { Pा } 242 \\
\text { An } 244\end{array}$ & $\begin{array}{l}400 \mathrm{E} 02 \\
202 \mathrm{E} 01\end{array}$ & $\begin{array}{l}4.00 E=04 \\
2.02 E-03\end{array}$ & $\begin{array}{l}4.00 E=08 \\
3.7 E+00\end{array}$ & $\begin{array}{l}1.60=-0 \% \\
7.01 E-00\end{array}$ & $\begin{array}{l}9.67=07 \\
3.76=03\end{array}$ & $\begin{array}{l}8.61 \mathrm{E} .05 \\
3.7 \mathrm{E}-01\end{array}$ \\
\hline & & $1.00 E+02$ & & & $1.86 E+00$ & $1.00 E+00$ & $1.00 E+02$ \\
\hline
\end{tabular}


Requisition Number: Container ID Number:

Package Gross Weight:

Package Gross Weight:

PK conc. @ MDA

Package Total Activity

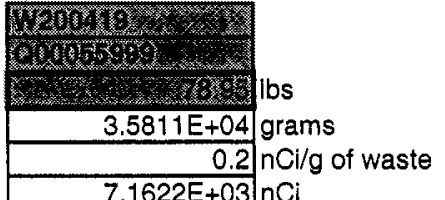

$7.1622 \mathrm{E}+03$

\section{\begin{tabular}{|l|l|l|l|l|l}
\hline 453.5924 & $g / b$ \\
\hline
\end{tabular}}

\section{Type of Pu}

Weapons Grade

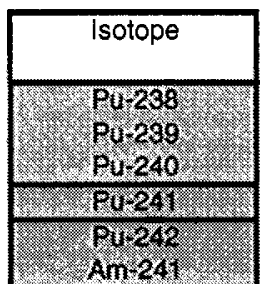

\begin{tabular}{lll} 
Wt. \% & Wt. Fraction \\
& \\
\hline $1.60 \mathrm{E}-02$ & $1.60 \mathrm{E}-04$ & 1.7 \\
$9.35 \mathrm{E}+01$ & $9.35 \mathrm{E}-01$ & 6.30 \\
$5.90 \mathrm{E}+00$ & $5.90 \mathrm{E}-02$ & 2.3 \\
$3.81 \mathrm{E}-01$ & $3.81 \mathrm{E}-03$ & 1.04 \\
$4.00 \mathrm{E}-02$ & $4.00 \mathrm{E}-04$ & 4. \\
$2.02 \mathrm{E}-01$ & $2.02 \mathrm{E}-03$ & 3.4 \\
\hline
\end{tabular}

Pu-238 Enhanced

\begin{tabular}{|c|}
\hline Isotope \\
\hline 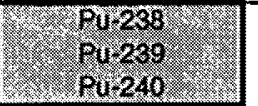 \\
\hline F. PUL4T: \\
\hline 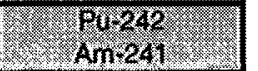 \\
\hline
\end{tabular}

\begin{tabular}{|c|c|c|c|c|c|c|}
\hline Wt. \% & Wt. Fraction & $\begin{array}{r}\mathrm{SpA} \\
(\mathrm{Ci} / \mathrm{g})\end{array}$ & $\begin{array}{c}\text { Mixture } \\
\mathrm{SpA} \\
(\mathrm{Ci} / \mathrm{g}) \\
\end{array}$ & $\begin{array}{l}\text { WGPU } \\
\text { Activity } \\
\text { Fraction }\end{array}$ & $\begin{array}{l}\text { Normalized } \\
\text { Activity fraction } \\
\text { w/o Pu-241 }\end{array}$ & $\begin{array}{c}\text { Package } \\
\text { Activity } \\
\text { Nano-Ci }\end{array}$ \\
\hline $8.02 E+00$ & $8.02 E-02$ & $1.73 \mathrm{E}+01$ & $1.39 \mathrm{E}+00$ & $7.47 E=01$ & $9.49 E-01$ & $600 \mathrm{E}+03$ \\
\hline $8.55 E+01$ & 8.55E-01 & $6.30 \mathrm{E}-02$ & 5.38E-02 & $2.90 E-02$ & $3.68 \mathrm{E}-02$ & $264 E+02$ \\
\hline $5.90 E+00$ & 5.90E-02 & 2.30E-01 & 1.36E-02 & 7.31E-03 & $9.29 \mathrm{E}-03$ & $6.65 E+01$ \\
\hline $3.81 E-01$ & 3.81E-03 & $1.04 E+02$ & $3.96 \mathrm{E}-01$ & $2.13 E-01$ & & 194222555 \\
\hline 4.00E-02 & 4.00E-04 & $4.00 \mathrm{E}-03$ & 1.60E-06 & 8.61E-07 & 1.09E-06 & $7784 \mathrm{E} 03$ \\
\hline 2.02E-01 & $2.02 E-03$ & $3.47 \mathrm{E}+00$ & 7.01E-03 & 3.77E-03 & 4.80E-03 & $3.44 \mathrm{E} .01$ \\
\hline $1.00 \mathrm{E}+02$ & & Total & $\begin{array}{l}1.86 E+00 \\
0\end{array}$ & $\frac{1.00 E+00}{3.07 F-01}$ & $\frac{1.00 E+00}{10}$ & $\frac{9.10 E+03}{716 F+03}$ \\
\hline
\end{tabular}

\section{Assumptions:}

1. All activities are at <MDA on the Blue Alpha survey meter.

2. Isotopic distribution of material is weapons grade Pu OR Pu-238 Enhanced.

3. Activity concentration is conservatively calculated based upon activity per unit mass as identified in the approved PK method.

4. See approved PK characterization process.

5. Weight must be measured on a calibrated scale.

Entered by:

Date:

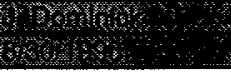


Requisition Number:

Container ID Number:

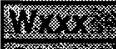

1960

0000068

Item TOTAL Gross Alpha Activity

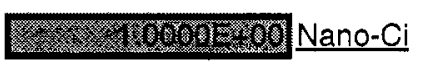

Weapons Grade

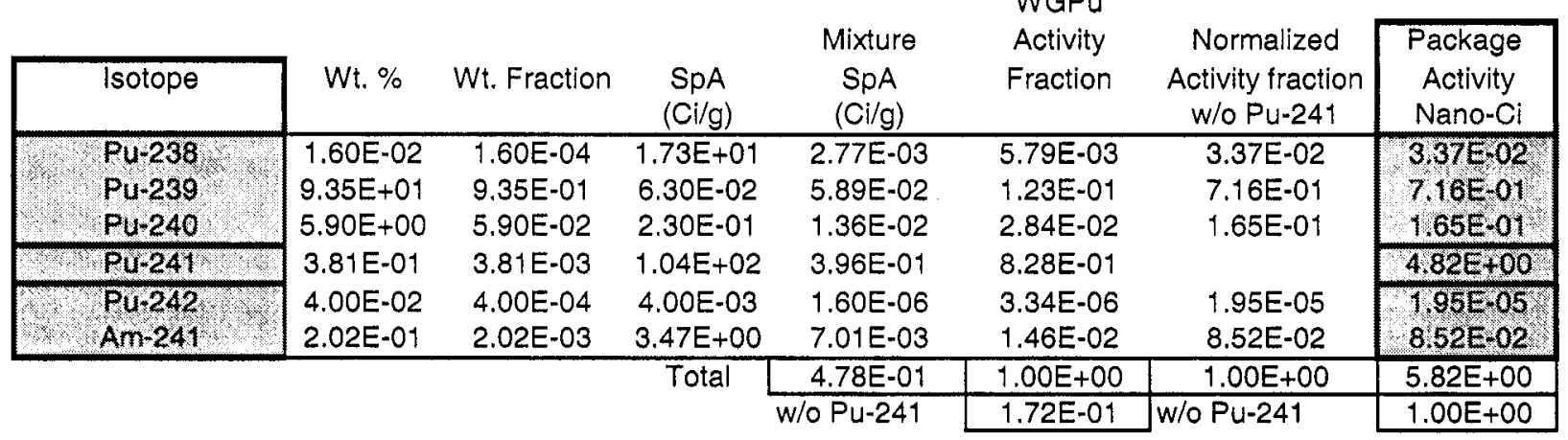

Type of Pu

Pu-238 Enhanced

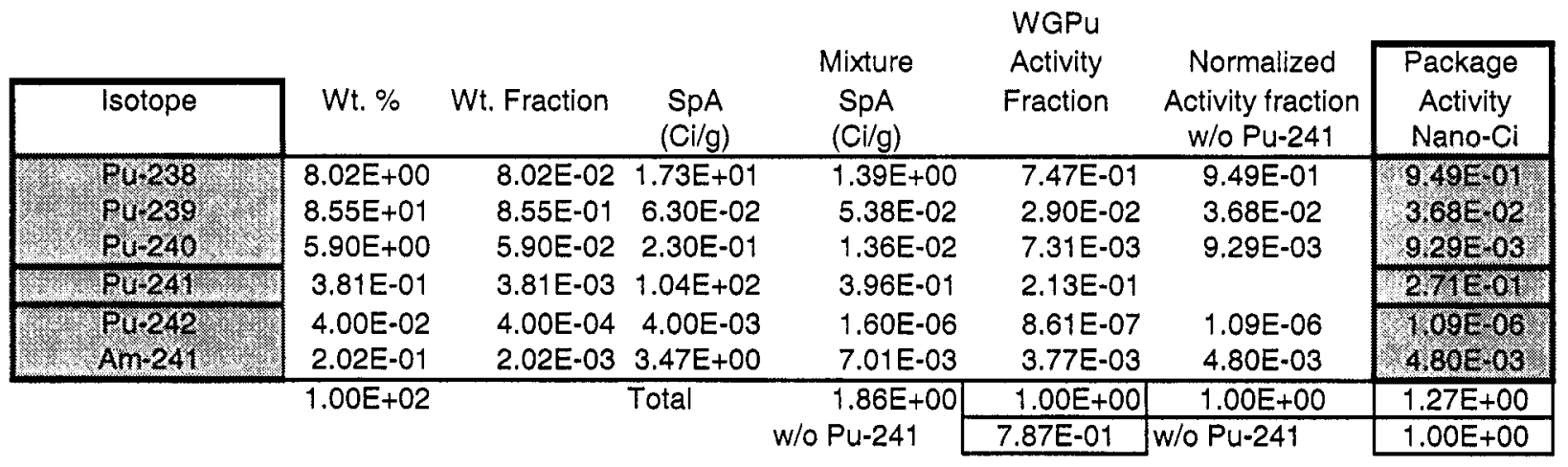

1. All activities are in NanoCuries from a documented survey or HP memo.

2. Isotopic distribution of material is weapons grade Pu OR PU-238 Enhanced.

3. Activity in the memo is total ALPHA activity.

Entered by:

Date:

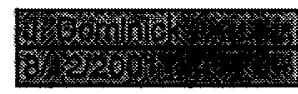


Item Identification (Q\#)

Item Identification (W\#)

CES COC Number/Sample ID

Total parcel Activity of Pu-239 reported by Gamma Spec (nCi)

Total mass of the parcel (grams)

Use MDA if activity is not identified.

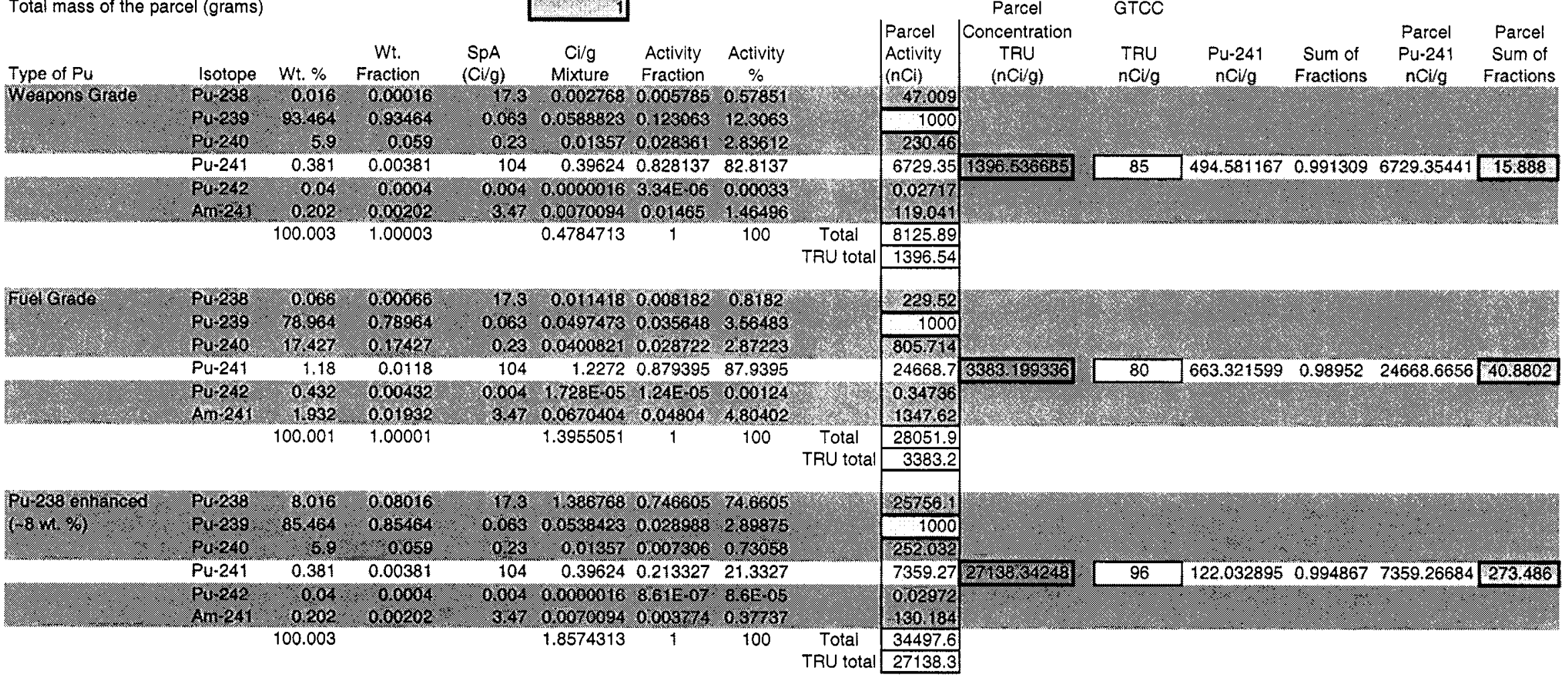

$\begin{array}{lr}\text { TRU Limit (20yr) } & \text { nCi/g } \\ \text { GTCC TRU Limit (5yr) } & 100 \\ \text { GTCC Pu-241Limit } & 3500\end{array}$


Item identification (W\#)

Item identification (Q\#)

CES COC Number/Sample ID

Total item Activity of Am-241 reported by Gamma Spec (nCi)

Total mass of the item (grams)

\begin{tabular}{|c|c|c|c|c|c|c|c|}
\hline Type of Pu & Isolope & WI. \% & Wt. Fraction & $\mathrm{SpA}(\mathrm{Ci} / \mathrm{g})$ & $\begin{array}{l}\mathrm{Ci} / \mathrm{g} \\
\text { Mixture }\end{array}$ & $\begin{array}{l}\text { Activity } \\
\text { Fraction }\end{array}$ & $\begin{array}{c}\text { Activity } \\
\%\end{array}$ \\
\hline feapons arade & 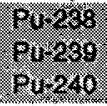 & $\begin{array}{r}0.096 \\
98.684 \\
5.9\end{array}$ & $\begin{array}{r}0.00016 \\
0.93464 \\
0.059\end{array}$ & $\begin{array}{r}17.3 \\
0.063 \\
0.28\end{array}$ & $\begin{array}{r}0.002768 \\
0.0588823 \\
0.01357\end{array}$ & $\begin{array}{l}0.005785 \\
0.128063 \\
0.028361\end{array}$ & $\begin{array}{l}0.67851 \\
123063 \\
2.83612\end{array}$ \\
\hline & Pu-241 & 0.381 & 0.00381 & 104 & 0.39624 & 0.828137 & 82.8137 \\
\hline & 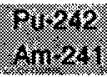 & $\begin{array}{l}0.04 \\
0.202\end{array}$ & $\begin{array}{l}0.0004 \\
0.00202\end{array}$ & $\begin{array}{r}0.004 \\
347\end{array}$ & $\begin{array}{l}0.0000016 \\
0.00 \% 0084\end{array}$ & $\begin{array}{c}3.34 E 06 \\
0.014655\end{array}$ & $\begin{array}{l}0.00033 \\
1.46496\end{array}$ \\
\hline & & 100.003 & 1.00003 & & 0.4784713 & 1 & 100 \\
\hline
\end{tabular}

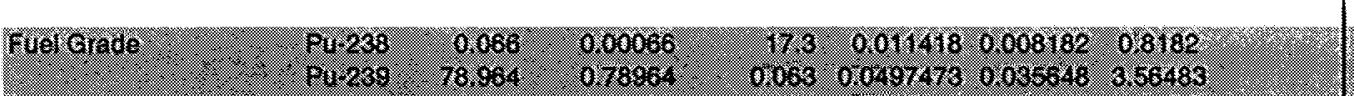

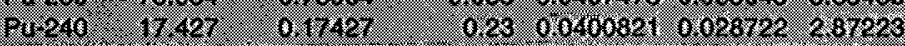

$\begin{array}{llllllll}\text { Pu-241 } & 1.18 & 0.0118 & 104 & 1.2272 & 0.879395 & 87.9395\end{array}$

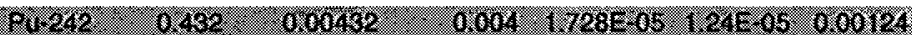

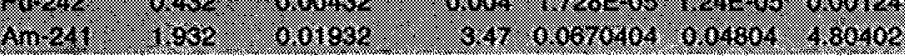

00.001

1.00001

1.3955051

1

100

Total

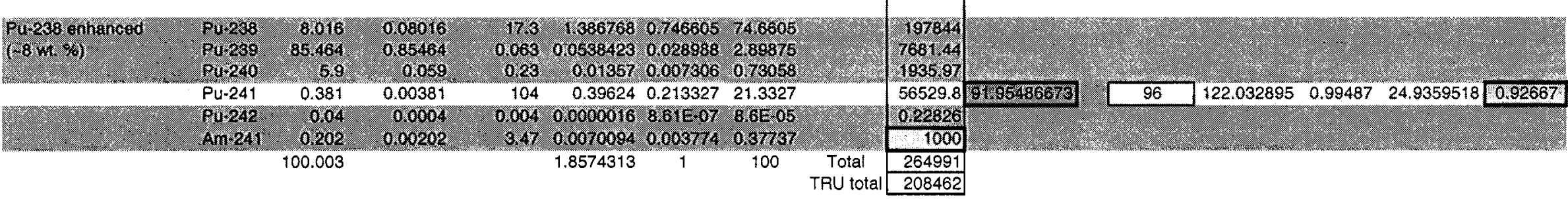

TRU total

Parcel GTCC

Parcel Concentration Parcel Parcel Activity TRU TRU Pu-241 Sum of Pu-241 Sum of (nCi) $\quad(n \mathrm{Ci} / 9) \quad \mathrm{nCl} / \mathrm{g} \quad \mathrm{nCl} / \mathrm{g}$ Fractions $\mathrm{nCl} / \mathrm{g}$ Fractions 394898 8400.48

1935970 0.22826 1000

68261.4

597.88

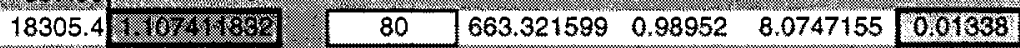
$0.25 \pi 76$

1000

20815.9

10784

7681.44

1936.97

$02282:$

TRU tota

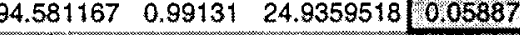

\begin{abstract}
TRU Limit (20yr)
$\mathrm{nCl} / \mathrm{g}$

GTCC TRU Limit (5yr)

100

GTCC Pu-241Limit

3500
\end{abstract}


Parcel Card Number:

Container ID Number:

High Swipe Result (dpm)

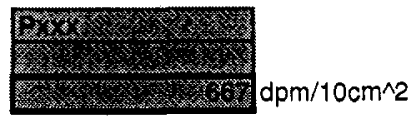

Alpha nCi/g of waste.

Measured parcel weight in grams.

Parcel TOTAL Gross Alpha Activity,

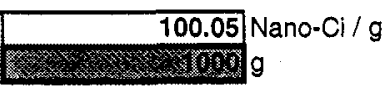

$1.0005 \mathrm{E}+05$ Nano-Ci

Type of Pu

Weapons Grade

\begin{tabular}{|c|}
\hline Isotope \\
\hline $\begin{array}{c}\text { Pu238 } \\
\text { puz239 } \\
\text { pu2 } 240\end{array}$ \\
\hline 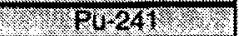 \\
\hline $\begin{array}{c}\text { Pu242 } \\
\text { Am-241 }\end{array}$ \\
\hline
\end{tabular}

\begin{tabular}{|c|c|c|c|c|c|c|}
\hline \multirow[b]{2}{*}{ Wt. \% } & \multirow[b]{2}{*}{ Wt. Fraction } & \multirow[b]{2}{*}{$\begin{array}{c}\mathrm{SpA} \\
(\mathrm{Cl} / \mathrm{g})\end{array}$} & & \multirow[b]{2}{*}{$\begin{array}{c}\text { Package } \\
\text { Activity } \\
\text { Nano-Ci }\end{array}$} \\
\hline & & & $\begin{array}{l}\text { Mixture } \\
\mathrm{SpA} \\
(\mathrm{Ci} / \mathrm{g})\end{array}$ & $\begin{array}{l}\text { Activity } \\
\text { Fraction }\end{array}$ & $\begin{array}{l}\text { Normalized } \\
\text { Activity fraction } \\
\text { w/o Pu-241 }\end{array}$ & \\
\hline 1.60E-02 & $1.60 \mathrm{E}-04$ & $1.73 E+01$ & $2.77 \mathrm{E} \cdot 03$ & $5.79 \mathrm{E}-03$ & $3.37 \mathrm{E}-02$ & $3.37 E+03$ \\
\hline $9.35 E+01$ & $9.35 \mathrm{E}-01$ & $6.30 \mathrm{E}$. & 5.8 & $1.23 \mathrm{E}-01$ & 7.1 & $7.16 E+04$ \\
\hline $5.90 E+00$ & $5.90 \mathrm{E}-02$ & $2,30 E-01$ & 1.36 & $2.84 \mathrm{E}-02$ & $1.65 \mathrm{E}-01$ & $165 E+04$ \\
\hline 3.81E-01 & $3.81 E-03$ & $1.04 E+02$ & $3.96 \mathrm{E}-01$ & $8.28 \mathrm{E}-01$ & & $482 E+05$ \\
\hline 4.00E-02 & $4.00 E=04$ & $4.00 \mathrm{E}-03$ & $1.60 \mathrm{E}-06$ & $3.34 \mathrm{E}-06$ & 1.5 & $1195 \mathrm{E}+00$ \\
\hline $2,02 \mathrm{E}=01$ & $2.02 E-03$ & $3.47 E+00$ & $7.01 \mathrm{E} \cdot 03$ & $1.46 \mathrm{E}-02$ & $E-02$ & 8.5 \\
\hline & & Total & $4.78 \mathrm{E} \cdot 01$ & $1.00 \mathrm{E}+00$ & $1.00 E+00$ & $5.82 E+05$ \\
\hline & & & & $1.72 \mathrm{E}-01$ & $10 \mathrm{Pu}-241$ & $1.00 E+05$ \\
\hline
\end{tabular}

Type of Pu

Pu-238 Enhanced

\begin{tabular}{|c|c|c|c|c|c|c|c|}
\hline & & & & & WGPU & & \\
\hline & & & & Mixture & Activity & Normalized & Package \\
\hline Isotope & Wt. \% & Wt. Fraction & $\begin{array}{c}\mathrm{SpA} \\
(\mathrm{Ci} / \mathrm{g})\end{array}$ & $\begin{array}{l}\mathrm{SpA} \\
(\mathrm{Ci} / \mathrm{g})\end{array}$ & Fraction & $\begin{array}{c}\text { Activity fraction } \\
\text { w/o Pu-241 }\end{array}$ & $\begin{array}{l}\text { Activity } \\
\text { Nano-Ci }\end{array}$ \\
\hline Pu:238 & $8.02 E+00$ & $8.02 E-02$ & $1.73 E+01$ & $1.39 E+00$ & $7.47 \mathrm{E}-01$ & $9.49 E-01$ & $9.50 \mathrm{E}+04$ \\
\hline $80-239$ & $8.55 E+01$ & $8.55 \mathrm{E}-01$ & $6.30 \mathrm{E}-02$ & $5.38 \mathrm{E}-02$ & $2.90 \mathrm{E}-02$ & $3.68 \mathrm{E}-02$ & $3.66 \mathrm{E}+03$ \\
\hline $\mathrm{Pu} 240$ & $5.90 \mathrm{E}+00$ & $5.90 \mathrm{E}-02$ & 2.30E-01 & $1.36 \mathrm{E}-02$ & 7.31E-03 & $9.29 \mathrm{E}-03$ & $9.29 \mathrm{E}+02$ \\
\hline PPU241 & 3.81E-01 & $3.81 \mathrm{E}-03$ & $1.04 \mathrm{E}+02$ & $3.96 \mathrm{E}-01$ & $2.13 \mathrm{E}-01$ & & $2.7 \mathrm{EE}+04$ \\
\hline PिO242 & $4.00 \mathrm{E}-02$ & $4.00 \mathrm{E}-04$ & $4.00 E=03$ & $1.60 \mathrm{E}-06$ & 8.61E-07 & $1.09 E-06$ & TTOE OI \\
\hline $\mathrm{Am}-241$ & $2.02 E-01$ & $2.02 \mathrm{E}-03$ & $3.47 E+00$ & 7.01E-03 & 3.77E-03 & $4.80 \mathrm{E}-03$ & $4.80 E+02$ \\
\hline & $1.00 E+02$ & & Total & $1.86 E+00$ & $1.00 E+00$ & $1.00 E+00$ & $1.27 E+05$ \\
\hline & & & & Pu-241 & $7.87 \mathrm{E}-01$ & W/O PU-241 & $1.00 \mathrm{E}+05$ \\
\hline
\end{tabular}

1. Assume both sides of the waste are contaminated

2. Assume all waste is contaminated at the highest level measured on the swipe.

3. A conservative areal density for 6 mil plastic is applied to all the waste $\left(1.2 \mathrm{E}-02 \mathrm{~g} / \mathrm{cm}^{\wedge} 2\right)$.

4. Assume swipe has a swipe area of $10 \mathrm{~cm} \wedge 2$.

5. Assume swipe efficiency is $5 \%$.

6. Swipe values are to be efficiency corrected alpha activity per swipe only. 
Parcel Card Number:

Container ID Number:

High Blue Alpha reading

Conversion to dpm.

Alpha $\mathrm{nCi} / \mathrm{g}$ of waste.

Measured parcel weight in grams.

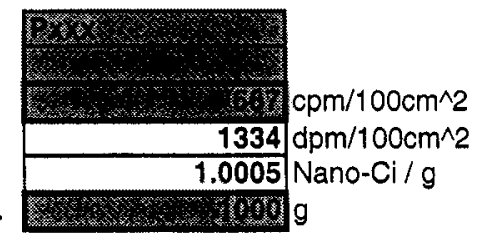

Parcel TOTAL Gross Alpha Activity

$1.0005 \mathrm{E}+03 \mathrm{Nano} \cdot \mathrm{C}$

Type of Pu

Weapons Grade

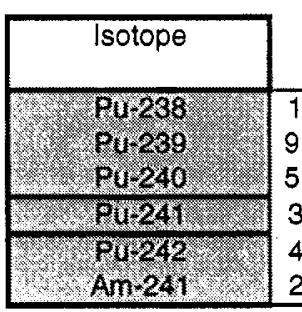

Wt. \% Wt. Fraction

$(\mathrm{Ci} / \mathrm{g})$

$\begin{array}{llll}1.60 \mathrm{E}-02 & 1.60 \mathrm{E}-04 & 1.73 \mathrm{E}+01 & 2.77 \mathrm{E}-03\end{array}$

9.35E +01 $9.35-01 \quad 6.30 \mathrm{E}-02 \quad 5.89 \mathrm{E}-02$

5.90E+00 5.90E-02 2.30E-01 1.36E-02

3.81E-01

3.96E-01

4.00E-04 4.00E-03 1.60E-06

2.02E-01

$2.02 \mathrm{E}-03$

\begin{tabular}{lll}
$3.47 \mathrm{E}+00 \quad 7.01 \mathrm{E}-03$ & $1.46 \mathrm{E}-02$ \\
\hline
\end{tabular}

WGPU

Activity Normalized Package

Fraction Activity fraction Activity

\begin{tabular}{lc|c|c} 
& W/O Pu-241 & Nano-Ci \\
\hline 5.79E-03 & $3.37 \mathrm{E}-02$ & $3.87 \mathrm{E}+01$
\end{tabular}

$\begin{array}{lll}1.33 \mathrm{E}-01 & 7.16 \mathrm{E}-01 & 716 \mathrm{E}+02\end{array}$

1.65E-01 20 05E

$1.65 \mathrm{E}-0$

$8.28 \mathrm{E}-01$

1.95E-05

\begin{tabular}{c|c|c|c|c|} 
Total & $4.78 \mathrm{E}-01$ & $1.00 \mathrm{E}+00$ & $1.00 \mathrm{E}+00$ & $5.82 \mathrm{E}+03$ \\
\cline { 2 - 6 }
\end{tabular}

\begin{tabular}{l|c|c|c|}
\hline W/O PU-241 & $1.72 E-01$ & $1.00 / 0$ PU-241 & $1.00 E+03$ \\
\cline { 2 - 3 }
\end{tabular}

Type of $\mathrm{Pu}$

Pu-238 Enhanced

\begin{tabular}{|c|c|c|c|c|c|c|c|}
\hline & \multirow[b]{3}{*}{ Wt. \% } & \multirow[b]{3}{*}{ Wt. Fraction } & & & \multirow{3}{*}{$\begin{array}{l}\text { WGPU } \\
\text { Activity } \\
\text { Fraction }\end{array}$} & \multirow{3}{*}{$\begin{array}{c}\text { Normalized } \\
\text { Activity fraction } \\
\text { w/o Pu-241 }\end{array}$} & \multirow{3}{*}{$\begin{array}{c}\text { Package } \\
\text { Activity } \\
\text { Nano-Ci }\end{array}$} \\
\hline & & & \multirow[b]{2}{*}{$\begin{array}{l}\mathrm{SpA} \\
(\mathrm{Ci} / \mathrm{g})\end{array}$} & Mixture & & & \\
\hline Isotope & & & & $\begin{array}{c}\mathrm{SpA} \\
(\mathrm{Ci} / \mathrm{g})\end{array}$ & & & \\
\hline \multirow{3}{*}{ 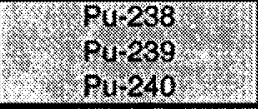 } & \multirow{4}{*}{$\begin{array}{l}8.02 E+00 \\
8.55 E+01 \\
5.90 E+00 \\
3.81 E-01\end{array}$} & \multirow{3}{*}{$\begin{array}{l}8.02 \mathrm{E}-02 \\
8.55 \mathrm{E}-01 \\
5.90 \mathrm{E}-02\end{array}$} & $1.73 E+01$ & \multirow{2}{*}{$1.39 \mathrm{E}+00$} & & \multirow{2}{*}{$9.49 \mathrm{E}-01$} & \multirow{2}{*}{$\begin{array}{l}950 \mathrm{E}+02 \\
360 \mathrm{E}+01\end{array}$} \\
\hline & & & \multirow{2}{*}{$\begin{array}{l}6.30 \mathrm{E}-02 \\
2.30 \mathrm{E}-01\end{array}$} & & & & \\
\hline & & & & 1.36E-02 & $\begin{array}{l}2.90 E-02 \\
7.31 E-03\end{array}$ & $\begin{array}{l}3.68 \mathrm{E}-02 \\
9.29 \mathrm{E}-03\end{array}$ & $9.29 E+00$ \\
\hline EIT. PU241 & & 3.81E-03 & $1.04 E+02$ & 3.96E-01 & & & $2716+02$ \\
\hline \multirow{2}{*}{$\begin{array}{l}\text { Pu-242 } \\
\text { Am-241 }\end{array}$} & $4.00 \mathrm{E}-02$ & $4.00 \mathrm{E}-04$ & $4.00 \mathrm{E}-03$ & $1.60 \mathrm{E}-06$ & $8.61 E-07$ & 1.09E-06 & $1710 \mathrm{E} 03$ \\
\hline & \multirow{3}{*}{$\frac{2.02 E-01}{1.00 E+02}$} & 2.02E-03 & $3.47 E+00$ & $7.01 \mathrm{E}-03$ & 3.77E-03 & 4.80 E-03 & $4.80 E+00$ \\
\hline & & & \multirow{2}{*}{ Total } & \multirow{2}{*}{$\begin{array}{l}1.86 \mathrm{E}+00 \\
\text { Pu-241 }\end{array}$} & $1.00 \mathrm{E}+00$ & $1.00 \mathrm{E}+00$ & $1.27 \mathrm{E}+03$ \\
\hline & & & & & 7.87E-01 & w/o Pu-241 & $1.00 \mathrm{E}+03$ \\
\hline
\end{tabular}

1. Assume both sides of the waste are contaminated

2. Assume all waste is contaminated at the highest level measured on the blue alpha.

3. A conservative areal density for 6 mil plastic is applied to all the waste $\left(1.2 \mathrm{E}-02 \mathrm{~g} / \mathrm{cm}^{\wedge} 2\right)$.

Entered by:

Date:

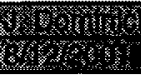

